\title{
INVENTARISASI RAGAM HIAS ACEH PADA ILUMINASI MUSHAF AL-QURAN KUNO KOLEKSI PEDIR MUSEUM DI BANDA ACEH
}

\author{
Niko Andeska ${ }^{1 *}$, Indra Setiawan ${ }^{2 *}$, Rika Wirandi $^{3 *}$ \\ Jurusan Seni Rupa dan Desain \\ Institut Seni Budaya Indonesia (ISBI) Aceh \\ Jl. Transmigrasi, Gampong Bukit Meusara, Kec. Kota Jantho, Kab. Aceh Besar, 23911. \\ Aceh. Indonesia \\ Email: nikoandeska@isbiaceh.ac.id
}

\begin{abstract}
Abstrak
Iluminasi atau seni naskah (the art of the book), dapat diartikan sebagai garapan visual yang bersifat dekoratif yang terdapat pada naskah yang berfungsi sebagai penghias. Pada dasarnya digunakan untuk memperindah bagian tertentu, terutama pada halaman depan naskah (frontispiece). Dalam naskah kuno karya ulama Aceh diketemukan berbagai bentuk iluminasi yang mengadopsi gaya ragam hias lokal Aceh. Keindahan iluminasi dalam khazanah naskah kuno karya ulama Aceh, terutama yang terdapat mushaf Al-Quran yang terhimpun menjadi koleksi lembaga-lembaga non pemerintah (swasta) di Kota Banda Aceh saat ini belum sepenuhnya tersentuh oleh kajian-kajian yang mengarah pada aspek rupa. Baik dari segi pendataan yang komprehensif hingga analisis mendalam dalam perspektif seni rupa.Penelitian yang berjudul "Inventarisasi Ragam Hias Aceh Pada Iluminasi Mushaf Al-Quran Kuno Koleksi Pedir Museum di Banda Aceh” bertujuan untuk mengkaji aspek rupa yang memfokuska n pada ragam hias Aceh pada iluminasi pada beberapa mushaf Al-Quran koleksi Pedir Museum. Penelitian ini menggunakan metode penelitian kuantitatif, dengan menggunakan teknik pengumpulan data melalui observasi, wawancara, dokumentasi, dan pendataan. Data-data yang telah terkumpul kemudian dilakukan proses pengindentifikasian, pengkatagorisasian, dan analisis data dengan mengunakan metode digitalisasi ragam hias pada beberapa mushaf Al-Quran koleksi Pedir Museum Banda Aceh. Penelitian ini diharapkan dapat mendata, mendokumentasikan, meninventarisir, serta analisis karakteristik ragam hias Aceh yang terdapat pada iluminasi mushaf Al-Quran koleksi Pedir Museum.
\end{abstract}

Kata Kunci: ragam hias Aceh, mushaf Al-Quran.

\begin{abstract}
Illumination or manuscript (the art of the book), can be interpreted as a decorative visual work that is contained in the manuscript that serves as a decoration. Basically used to beautify certain parts, especially on the front page of the script (frontispiece). In ancient manuscripts by Acehnese scholars, various forms of illumination were adopted which adopted the local Acehnese decorative style. The beauty of illumination in the treasures of ancient manuscripts by Acehnese ulama, especially those contained in the Al-Quran Manuscripts compiled into a collection of non-governmental institutions (private) in the city of Banda Aceh at this time has not been fully touched by studies that lead to visual aspects. Both in terms of comprehensive data collection to in-depth analysis in the perspective of fine arts. The study entitled "Inventory of Aceh Ornamental Variations in Illumination of Ancient Al-Quran Manuscripts in the Pedir Museum Collection in Banda Aceh" aims to examine visual aspects that focus on the Acehnese ornamental variety in illuminations on several Al-Quran Manuscripts from the Pedir Museum collection. This research uses quantitative research methods, using data collection techniques through observation, interviews, documentation, and data collection. The data that has been collected is then carried out the process of identifying, categorizing, and analyzing the data by using the digitizing method of ornamental variance in several Al-Quran Manuscripts from the Banda Aceh Pedir Museum collection. This research is expected to be able to record, document, inventory, and analyze the characteristics of Aceh's ornamental variations found in the illumination of the Al-Quran Manuscripts from the Pedir Museum collection.
\end{abstract}

Keywords: variety of ornamental Aceh, Al-Quran manuscripts.

\section{PENDAHULUAN}

Aceh merupakan satu dari sekian banyak daerah di Indonesia yang memilik i kebudayaan dengan corak keislaman. Hal ini dapat dilihat di berbagai sendi kehidupan masyarakat lokalnya hingga saat ini. Di samping itu, corak keislaman dalam kebudayaan lokal 
masyarakat Aceh juga mucul dan termanifestasi dalam bentuk karya-karya visual yang begitu beragam. Salah satu di antaranya berupa naskah kuno karya ulama Aceh (selanjutnya ditulis : NKKUA).

Ulama-ulama atau cendikiawan muslim Aceh dahulunya mentransfer ilmu pengetahuan menggunakan media naskah atau juga dikenal dengan istilah manuskrip. Hal ini dilakukan sebagai bentuk pembendaharaan ilmu pengetahuan, ide-ide, dan nilainilai yang bernapaskan Islam pada saat itu.

Manuskrip secara umum dapat diartikan sebagai naskah yang ditulis secara manual atau tulis tangan pada media kertas. NKKUA (naskah kuno karya ulama Aceh) biasanya dibuat untuk berbagai kebutuhan tertentu yang berorientasi pada aktivitas penyebaran ajaran Islam. Selain itu, naskah tersebut hadir sebagai bentuk kerja dokumentasi tertulis yang berperan untuk penyebaran ilmu pengetahuan yang terpusat di lembaga-lembaga pendidikan tradisional Islam di Aceh: meunasah, dayah, dan sebagainya.

NKKUA (naskah kuno karya ulama Aceh) yang lahir dari budaya literasi Islam di Aceh, terbagi dalam beberapa jenis, di antaranya kitab-kitab ilmu pengetahuan tentang keislaman dan mushaf Al-Quran. Khusus untuk muhaf Al-Quran, ditulis tangan serta memiliki iluminasi pada bagian-bagian tertentu. Iluminasi atau seni naskah (the art of the book), dapat diartikan sebagai garapan visual pada naskah yang berfungsi untuk penghias pada lembar-lembar tertentu. Penyertaan iluminasi dalam beberapa jenis NKKUA (naskah kuno karya ulama Aceh) juga berfungsi sebagai bentuk cerminan identitas kelokalan masyarakat pemiliknya. Indikasinyanya dapat dilihat melalui karakter garapan corak ornamentasinya pada seni naskah yang cenderung mengarah pada pengadopsian ragam-ragam hias tradisional Aceh pada umumnya.

Menurut Guntur, seni rupa Islam justru berkarakter karena larangan penggambaran makhluk hidup. Karya seni non-representatif dan dekoratif merupakan dimensi unik dari produk kesenian Islam (Guntur. 2004:92). Oleh karena itu, dalam tradisi menghias bagian dan lembar tertentu pada NKKUA, cenderung menghadirkan corak-corak ragam hias berbentuk floral.

Upaya penyelamatan NKKUA (naskah kuno karya ulama Aceh) oleh beberapa lembaga non pemerintah (swasta) saat ini di Kota Banda Aceh, termasuk di dalamnya Pedir Museum - belum sepenuhnya dibarengi dengan upaya pendataan dan penginventarisasian ragam hias dalam iluminasi naskah kunonya. Hal ini berbanding terbalik dengan upaya yang mengarah pada pendataan maupun kajian yang mendalam terhadap aspek filologi yang cenderung berkembang pesat beberapa dekade terakhir, baik yang dilakukan oleh pengurus lembaga yang bersangkutan maupun akademisi dan peneliti. Di pihak lain, seni naskah (the art of the book) sejauh ini tampaknya masih kurang mendapat perhatian dari peminat kajian naskah Nusantara (Akbar. 2017: 1).

Berangkat permasalahan kondisi artefak-artefak NKKUA (naskah kuno karya ulama Aceh) hari ini yang cukup memprihatinkan, serta masih rendahnya kepedulian dalam hal pelestarian, pendokumentasian, dan pendataan yang mengkhususkan pada aspek ragam hias dalam iluminasi. Ditambah dengan masih sangat minimnya kajian yang mengarah pada aspek rupa yang terdapat pada mushaf Al-Qur'an koleksi Pedir Museum di Banda Aceh yang belum sepenuhnya terdata secara intensif. Maka penelitian ini begitu penting untuk dilakukan sebagai sebuah upaya kajian yang mengarah pada kerja pendokumentasian data visual dan inventarisasi ragam hias Aceh dalam iluminasi mushaf Al-Qur'an karya ulama Aceh koleksi museum tersebut.

\section{KAJIAN TEORI}

Aceh merupakan salah satu tempat lahirnya naskahnaskah keagamaan, yang ditulis oleh para ulamaulama ternama di masanya. Penyebaran ajaran Islam sudah dimulai pada abad ke-7 dan mengalami perkembangan yang pesat pada masa Kesultanan Samudera Pasai pada abad ke-13 masehi (Akbar ,dkk. 2017: 13). Masa-masa hadir dan berkembangnya ajaran Islam di Aceh membawa dampak yang signifikan terhadap kehadiran naskah keislaman karya ulama pada massa itu, terutama untuk jenis mushaf Al-Quran.

Berbicara tentang naskah-naskah kuno karya ulama Aceh, terdapat dua konten karakteristik di dalamnya, yang pertama yaitu konten yang berisi tentang ajaran dan ilmu pengetahuan Islam. Kedua terdapat konten iluminasi yang digarap dengan menggunakan ragam hias sebagai suatu sarana untuk menghias dan mendekorasi yang banyak dijumpai pada mushaf AlQuran. Berdasarkan dari perbandingan dengan sumber kajian yang telah dilakukan oleh peneliti sebelumnya, upaya untuk penspesifikakan kajian ke ranah iluminasi mushaf Al-Quran sangat jarang ditemui.

Bukti peninggalan khazanah Islam dalam bentuk mushaf Al-Quran dan kitab-kitab ilmu pengetahuan 
karya ulama Aceh lainya, masih terpelihara dengan baik sampai sekarang ini. Hal ini dapat terwujud berkat kesadaran akan upaya penyelamatan artefak sejarah dari pihak-pihak lembaga instansi pemerintahan maupun swasta. Dalam kurun satu dekade terakhir, instans i-instansi tersebut mulai bergerak sebagai sebuah bentuk kesadaran untuk menyelamatkan, dan mengumpulkan naskah-naskah kuno. Pedir Museum merupakan satu dari sedikitnya lembaga swasta di Banda Aceh yang memfokuskan pada kerja pengumpulan dan penyelamatan naskahnaskah kuno Aceh. Berdasarkan informasi yang didapatkan, kajian-kanjian naskah kuno koleksi Pedir Museum banyak dijadikan sebagai objek penelitian filologi dan teks naskah. Sedangkan kajian dalam iluminasi manuskrip ini sangat minim dilakukan.

Masih kecilnya kerja penelitian yang menyasar pada kajian iluminasi mushaf Al-Quran, maka penelitian yang berjudul, "Inventarisasi Ragam Hias Aceh Pada Iluminasi Mushaf Al-Quran Kuno Aceh Koleksi Pedir Museum di Banda Aceh", perlu dilakuan sebagai upaya menelusuri tentang permasalahan iluminasi yang mengidentikkan ragam hias Aceh sebagai bentuk corak budaya tempat dimana naskah tersebut ini beredar. untuk itu perlu rasanya melakukan pendekatan konseptual dalam upaya untuk melakukan penganalisaan . maka untuk itu perlu melakukan pendekatan konseptual penganalisasian webster dalam katalog Kalam Kalam Ilahi mengatakan Iluminasi (illumination) berasal dari akar kata "Iluminate" yang berarti to light up, to make brike: to decorate: to enlighten spiritually or intellectually (websterb1992:390). yang berarti bahwan hiasan yang berfungs i sebagai "penerang"bagi teks yang ditampilkan dalam Mushaf Alquran (2017:34). Menurut Pemaparan di atas dapat dipahami jika di hubungkan dengan konteks iluminasi mushaf AlQuran kuno Aceh bahwa iluminasi sebagai penerang yang tergarap, mengunakan pencapaian visual yang akan menapilkan karater ke acehannya, hal ini terlihat di dalam metoda penggarapan visualnya sebagai ke khasan aceh pada iluminasi, menggunakan pola kecenderungan penciptaan visual seperti kulah Kama (Mahkota), Lungke Keubeu (Tanduk kerbau), Tameh Puntong (Tiang), serta Taloe puta (Tali Putar).

Ragam hias Aceh sebagai bentuk karya seni rupa tradisional menurut Prof Dharsono pola karya seni tradisi ini dijelaskan seperti table berikut:

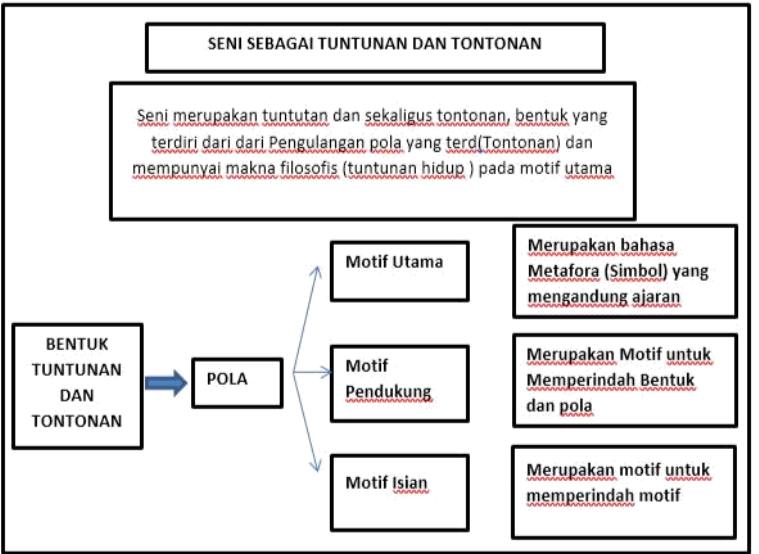

Gambar 1. Ragam Hias Aceh sebagai Bentuk Karya Seni Rupa (Sumber: Dharsono Sony Kartika, 2019: 87)

Ragam hias Aceh dapat dikatakan sebagai karya seni rupa tradisional yang tidak hanya sebagai pengindah akan tetapi juga sebagai tuntunan bagi masyarakatnya. Terkait dengan demikian jika dihubungkan dengan penerapan ragam hias pada iluminasi Al-Quran ini perlu dianalisis secara mendalam sebagai sarana untuk pengiventarisasian identitas budaya Aceh. Berangkat dari landasan diatas, maka dapat targetkan peta jalan penelitian ini dengan bagan sebagai berikut:

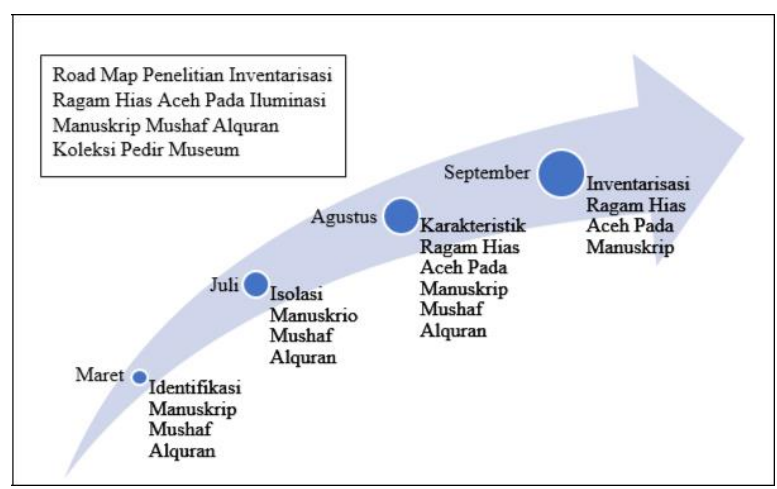

Gambar 2. Bagan Road Map Jalannya Penelitian (Sumber: Niko Andeska, 2019)

Penelitian ini akan menggunakan sumber-sumber relevan dalam bentuk buku yang bisa dijadikan sebagai rujukan dan perbandingan untuk memperkuat konsep dan gagasan dalam penelitian. Buku-buku yang akan dijadikan sumber referensi yang relevan, di antaranya buku yang berjudul: "Kalam-Kalam Ilahi Yang Tergugat Diatas Batu Hingga Kertas Moderen"; "Mushaf Kuno Nusantara Pulau Sumatera"; “ Kemilau Warisan Budaya Aceh".

Buku "Kalam -Kalam Ilahi- Yang Tergugat di Atas Batu hingga Kertas Modern" tulisan Dr. Muclich M. Hanafi Ma, adalah buku yang di dalamnya terdapat pembahasan tentang sejarah-sejarah penulisan awal sampai tradisi penyalinan mushaf Al-Quran secara tradisional. Buku yang disebutkan di atas juga 
membahas sedikit tentang permasalahan iluminasi dengan gaya Aceh. Namun, di dalam buku ini tidak terdapat pembahasan yang dalam tentang permasalahan penggarapan iluminasi yang menggunakan penempatkan ragam hias Aceh. Sehingga dalam pengindentifikasian belum terdata dengan baik terkait apa saja yang tergarap pada iluminasi mushaf Al-Quran kuno. Mengingat bahwa iluminasi merupakan salah satu bentuk karya seni rupa tradisi yang memvisualkan corak ragam hias Aceh.

Buku selanjutnya "Mushaf Kuno Nusantara Pulau Sumatera" terbitan Lajna Pentashihan Mushaf AlQuran Badan Litbang dan Diklat Kementrian Agama RI tahun 2017. Buku ini menjelaskan tentang banyaknya temuan salinan mushaf Al-Quran yang tersebar di Nusantara, khususnya pulau Sumatera. Temuan naskah kuno di dalam buku ini dikategorikan berdasarkan daerah peredaran dan corak visual dari masing daerah. Pada buku ini juga telah menyinggung tentang iluminasi yang terdapat dalam mushaf AlQuran. Dalam buku tersebut dikatakan bahwa, iluminasi pada mushaf Al-Quran lebih banyak mengembangkan ragam hias flora. Akan tetapi pembahasan tersebut masih belum terperinci, terutama mengenai kecenderungan penempatan ragam hias Aceh pada iluminsasi mushaf Al-Quran kuno tersebut.

Buku dengan judul "Kemilau Warisan Budaya Aceh" Tulisan H. Harun Keuchik Leumiek. Buku ini menjelaskan bahwa manuskrip sebagai pembendaharaan ilmu pengetahuan oleh para ulama terdahulu yang menggambarkan kemajuan tingkat intelektual dan ilmu pengetahuan yang pernah berkembang di aceh pada abad-abad kemajuannya. Sedangkan pembahasan tentang iluminasi tidak ada disinggung dalam buku ini. Sehingga dapat dikatakan bahwa sumber ini hanya berfokus kepada fungsi dan kegunaannya.

Berdasarkan perbandingan dari beberapa buku yang relevan dari kajian pustaka di atas dapat disimpulkan bahwa kajian yang lebih mengulas masalah iluminasi pada mushaf Al-Quran ini sangat minin sebagai sebuah bentuk pengetahuan. Pembahasan ragam hias Aceh yang terdapat pada iluminasi mushaf Al-Quran belum banyak disentuh oleh para akademisi dan peneliti. Maka dari itu, penelitian ini dilakukan guna menginventarisasi ragam hias Aceh yang terdapat pada iluminasi mushaf Al-Quran.

\section{METODE PENELITIAN} 1.Rancangan Penelitian
Penelitian yang berjudul, "Inventarisasi Ragam Hias Aceh Pada Iluminasi mushaf Al-Quran Kuno Aceh Koleksi Pedir Museum di Banda Aceh" ini akan melakukan penelitian dengan menggunakan pendekatan metode kualtitatif. Metode Kualitatif ini dilakukan dengan cara mengumpulkan informasi dengan cara penentuan objek dan topik, observasi, penentuan informan, wawancara, pengambilan data sampai analisis data yang terkait dengan Iluminas i pada mushaf Al-Quran kuno Aceh.

\section{Lokasi}

Lokasi penenelitian ini akan dilakukan di daerah Banda Aceh tepatnya di Pedir Museum Banda Aceh yang merupakan sebuah lembaga swasta yang bergerak dibidang pengkoleksian beda-benda warisan budaya termasuk Manuskrip Aceh. Tempat ini digunakan sebagai tempat penelitian dikarenakan selain tempat ini terbuka bagi pihak-pihak pengaksesan manuskrip, dan juga tempat ini memiliki sumberdaya informan yang memadai secara ilmu pengetahunnya. Sehingga di dalam penelitian yang akan dilakukan ini dapat dipermudah dalam sarana mengumpulkan data dan mengakses data.

\section{Teknik Pengumpulan Data}

Pengumpulan data yang akan dilakukan dalam penelitian ini bersifat kualititatif dimana pada prosesnya dilakukan dengan proses wawancara kepada informan baik secara langsung maupun tidak langsung, direkam dan didokumentasikan sebagai pembendaharaan data pada saat proses wawancara. Selanjutnya untuk pendokumentasian koleksi manuskrip mushaf Al-Quran kuno koleksi Pedir Museum, dilakukan sebagai upaya untuk dapat menganalisa corak Ragam Hias khas Aceh yang terdapat di dalam manuskrip Mushap Al-Quran.

\section{Teknik Analisis Data}

Data yang telah didapatkan dari Pedir Museum ini pada nantinya akan diolah dan dipilah-pilah sesuai dengan kebutuhan yang lebih spesifik terkait dengan iluminasi mushaf Al-Quran kuno Aceh. Membedah iluminasi mushaf Al-Quran kuno Aceh berdasarkan pendekatan teori yang digunakan sebagai pisau bedah untuk mengungkap kecenderungan ragam hias aceh yang teraplikasikan ke dalam visual iluminasi.

\section{HASIL DAN PEMBAHASAN \\ 1.Hasil}

Berdasarkan hasil analisis yang dilakukan terhadap mushaf Al-Quran kuno Aceh di Pedir Museum dapat dijabarkan sebagai berikut: 


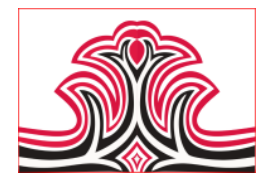

Mushaf Al-Quran kuno Aceh yang masih memiliki halaman utuh dan dapat di inventarisir adalah sebanyak tiga mushaf. Tiga buah muashaf al-quran kuno Aceh yang terdapat di pedir museum tersebut sudah tidak di ketahui penyalin dan pembuat iluminasinya. Pada tiga mushaf tersebut, iluminasi berupa ragam hias aceh terdapat pada pertengahan mushaf.

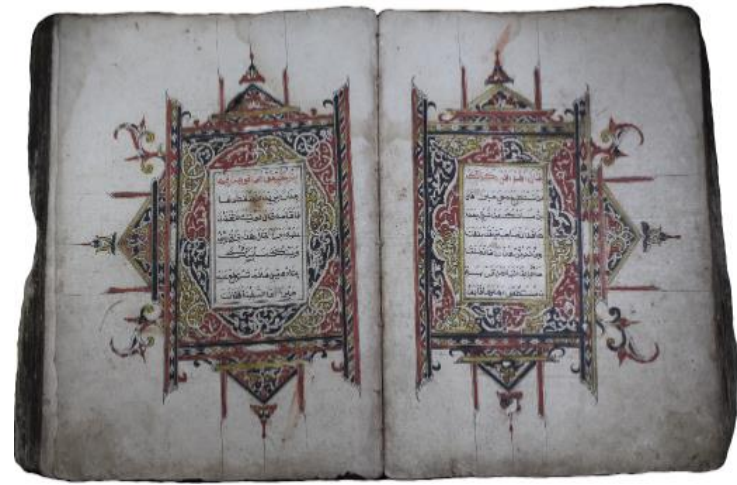

Gambar 3. Mushaf Al-Quran Kuno Aceh 1 (Sumber: Indra Setiawan, 2019)

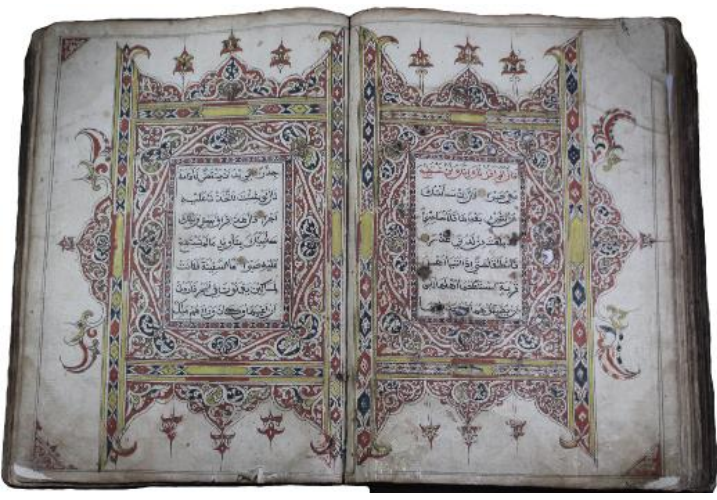

Gambar 4. Mushaf Al-Quran Kuno Aceh 2 (Sumber: Indra Setiawan, 2019)

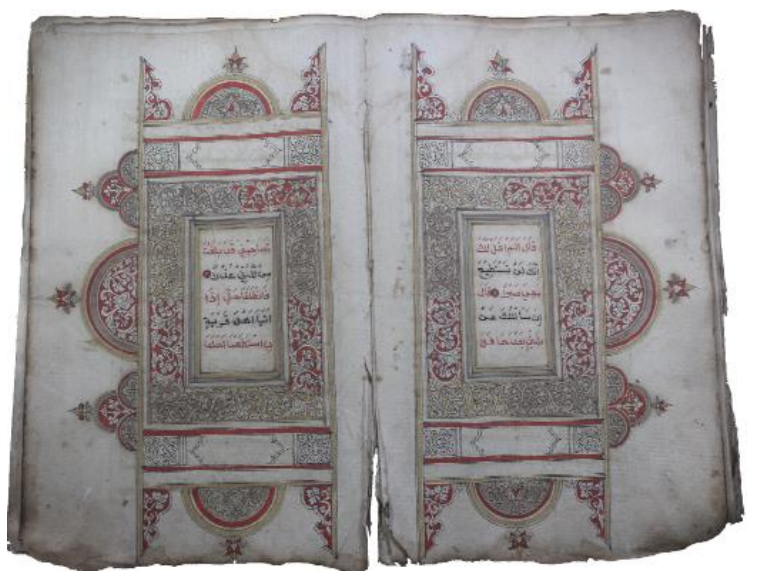

Gambar 5. Mushaf Al-Quran Kuno Aceh 3

(Sumber: Indra Setiawan, 2019)
Gorga Jurnal Seni Rupa

Volume 08 Nomor 02 Juli-Desember 2019 p-ISSN: 2301-5942 | e-ISSN: 2580-2380

\section{Pembahasan}

Pada mushaf Al-Quran kuno Aceh dilakukan pendigitalisasian dan analisis ragam hias dengan membandingkan motif aceh yang terdapat pada buku "arsitektur seni rupa aceh, 1996" dan buku "tangan tangan terampil seni kerajinan Aceh, 1989". Maka ditemukan sebanyak 12 motif pada mushaf Al-Quran kuno Aceh yang menyerupai motif-motif aceh berikut beberapa sketsa yang menyerupai motif-motif pada mushaf Al-Quran kuno:

Tabel 1. Sketsa yang Menyerupai Motif Aceh

\begin{tabular}{|c|c|c|}
\hline $\begin{array}{l}\text { Nama } \\
\text { Motif }\end{array}$ & Gambar & Keterangan \\
\hline $\begin{array}{l}\text { Motif } \\
\text { bungong } \\
\text { avu-avu }\end{array}$ & & $\begin{array}{l}\text { Motif bungong } \\
\text { seuleupo } \\
\text { merupakan salah } \\
\text { satu motif tenum } \\
\text { sutera pada } \\
\text { hiasan tepi kain } \\
\text { dari masa } \\
\text { lampau }\end{array}$ \\
\hline $\begin{array}{l}\text { Motif } \\
\text { bungong } \\
\text { pucuk } \\
\text { rebung }\end{array}$ & & $\begin{array}{l}\text { Motif bongong } \\
\text { seuleupo } \\
\text { merupakan galah } \\
\text { satu motif tenum } \\
\text { sutera dari masa } \\
\text { lampau. }\end{array}$ \\
\hline $\begin{array}{l}\text { Motif } \\
\text { bungong } \\
\text { sagos }\end{array}$ & & $\begin{array}{l}\text { Motif bungong } \\
\text { seuleupo } \\
\text { merupakan salah } \\
\text { satu motif tenum } \\
\text { sutera dari masa } \\
\text { lampau } \\
\text { diteraphan pada } \\
\text { hiasan gudut } \\
\text { kain }\end{array}$ \\
\hline $\begin{array}{l}\text { Motif } \\
\text { bungong } \\
\text { awan- } \\
\text { awan }\end{array}$ & & $\begin{array}{l}\text { Motif bungong } \\
\text { seuleupo } \\
\text { merupakan } \\
\text { salah satu motif } \\
\text { tenum sutera dari } \\
\text { masa lampau }\end{array}$ \\
\hline $\begin{array}{l}\text { Motif } \\
\text { bungong } \\
\text { kundo }\end{array}$ & & $\begin{array}{l}\text { Motif bongong } \\
\text { seuleupo } \\
\text { merupakan salah } \\
\text { satu motif tenum } \\
\text { sutera dari masa } \\
\text { lampau }\end{array}$ \\
\hline
\end{tabular}



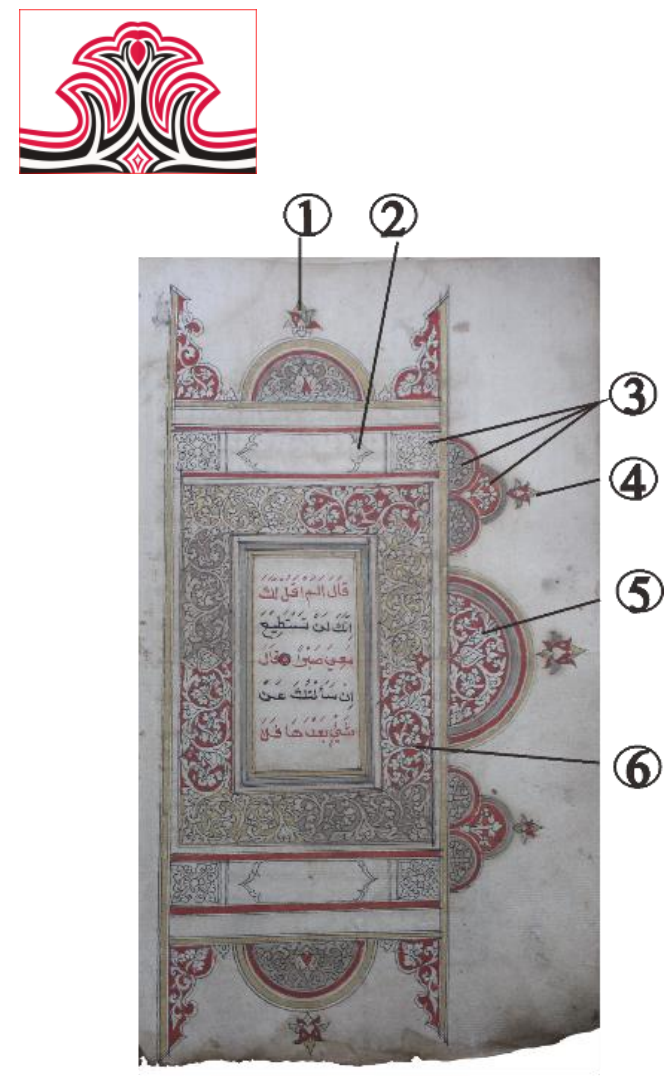

Gambar 6. Mushaf Al-Quran 1

(Sumber: Indra Setiawan, 2019)

Keterangan:

1. Motif bungong aуu-ayu

2. Motif bungong pucuk rebung

3. Motif bungong sagoe

4. Motif bungong sulu bayong

5. Motif awan si on

6. Motif bungong awan-awan

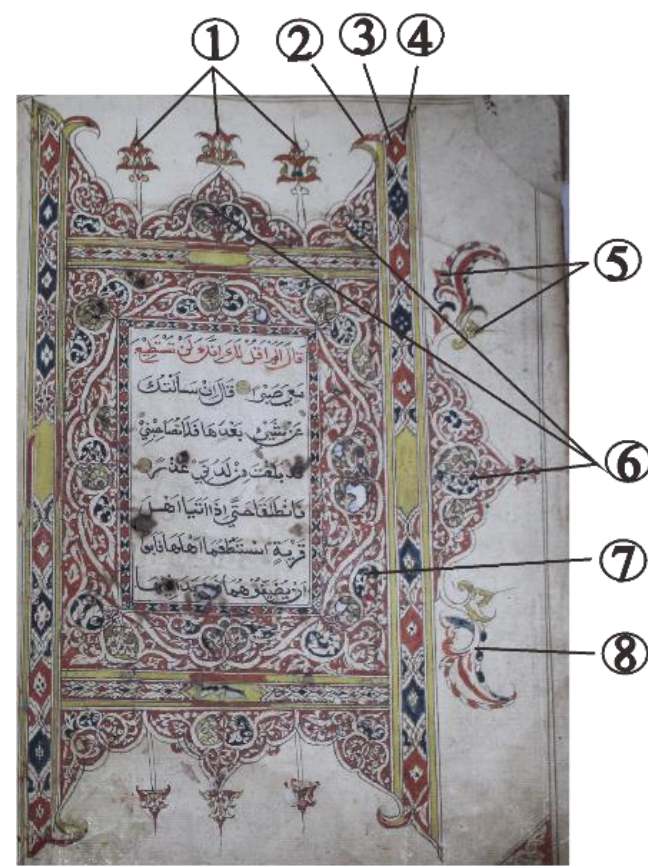

Gambar 7. Mushaf Al-Quran 2

(Sumber: Indra Setiawan, 2019)

Keterangan:

1. Motif bungong ayu-ayu
Gorga Jurnal Seni Rupa

Volume 08 Nomor 02 Juli-Desember 2019 p-ISSN: 2301-5942 | e-ISSN: 2580-2380

2. Motif bengkuang rincong

3. Motif bungong seuleupo

4. Motif bungong pucuk rebung

5. Motif kuncep

6. Motif awan si on

7. Motif bungong aka cino dan Motif awan si on

8. Motif kuncup bunga

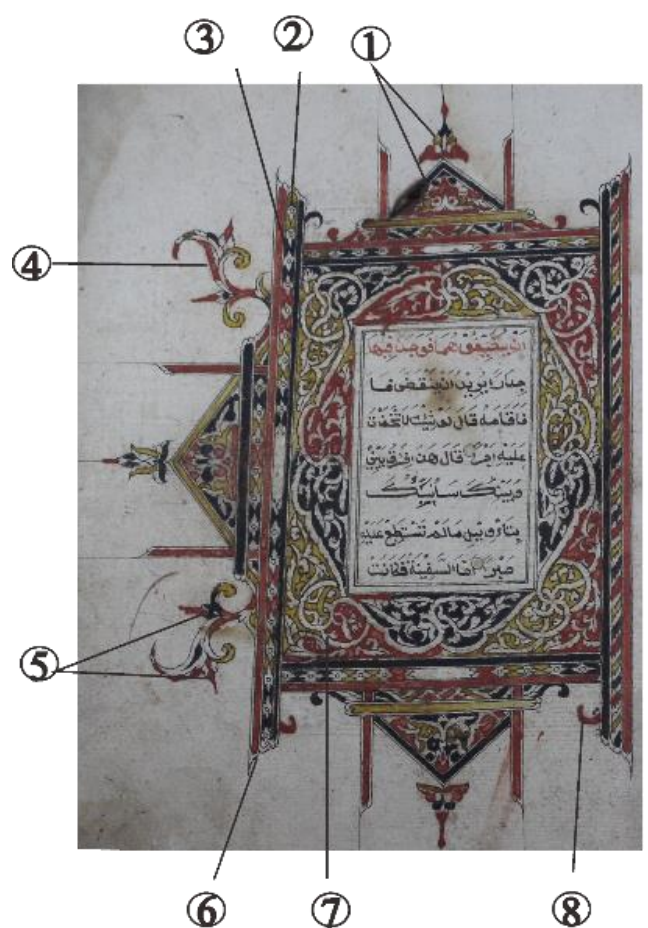

Gambar 8 Mushaf Al-Quran 3

(Sumber: Indra Setiawan, 2019)

Keterangan:

1. Motif bungong sagoe

2. Motif bungong pucuk rebung

3. Motif bungong seuleupo

4. Motif kuncup bunga

5. Motif kuncep

6. Motif kuncup bunga

7. Motif bungong kundo

8. Motif bengkuang rincong

\section{KESIMPULA DAN SARAN}

\section{Kesimpulan}

Ragam hias Aceh dapat dikatakan sebagai karya seni rupa tradisional yang tidak hanya sebagai pengindah akan tetapi juga sebagai tuntunan bagi masyarakatnya. Terkait dengan demikian Kajian yang lebih mengulas masalah iluminasi pada mushaf Al-Quran ini sangat minin sebagai sebuah bentuk pengetahuan. Pembahasan ragam hias Aceh yang terdapat pada iluminasi mushaf Al-Quran belum banyak disentuh oleh para akademisi dan peneliti. 


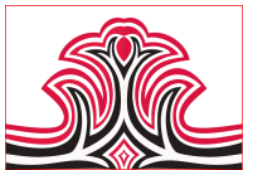

Minimnya penelitian pada mushaf Al-Quran berdampak pada pengetahuan dan kepedulian terhadap keberadaan mushaf Al-Quran yang sudah tua. Sehingga jumlah mushaf Al-Quran yang masih utuh sangat sedikit dan kebanyakan yang tersisa hanya lembaran-lembaran mushaf Al-Quran tersebut. Seperti halnya di Pedir Museum, jumlah koleksi mushaf AlQuran yang masih utuh hanya sebanyak 3 buah mushaf.

\section{Saran}

Saran yang dapat disampaikan pada laporan kemajuan penelitian dengan judul "Inventarisasi Ragam Hias Aceh Pada Iluminasi Mushaf Al-Quran Kuno Koleksi Pedir Museum di Banda Aceh" ialah masyarakat pada umumnya dan akademisi pada khususnya agar lebih memperhatikan karya tradisi sehingga tidak hilang karena kemajuan zaman.

\section{DAFTAR RUJUKAN}

Akbar, dkk. (2017). MUSHAF KUNO NUSANTARA Pulau Sumatera. Jakarta: Lajnah Pentasbihan Mushaf Al-Qur'an Badan Litbang dan Diklat Kementerian Agama RI.

Badan Litbang dan Diklat Kementerian Agama RI.

(2017). Kalam Kalam Ilahi. Jakarta: Bayt AlQur'an Dan Museum Istiqlal.

Guntur. (2004). Ornamen: Sebuah Pengantar.

Surakarta: P2AI bekerja sama dengan STSI Press.

Kartika, Dharsono Sony. (2016). Kreasi Artistik. Karanganyar: Citra Sain.

Leumiek, Harun Keuchik. (2016). Kemilau Warisan Budaya Aceh Koleksi Pilihan Museum Pribadi H. Harun Keuchik Leumiek. Banda Aceh: Toko Emas Permata dan Souvenir H. Harun Keuchik Leumiek. 